\title{
Predicting balsam fir growth reduction caused by spruce budworm using large-scale historical records of defoliation
}

\author{
David POTHIER $^{a *}$, Daniel MAILly ${ }^{\mathrm{b}}$, Stéphane TREMBLAY ${ }^{\mathrm{b}}$ \\ a Département des Sciences du bois et de la forêt, Université Laval, Sainte-Foy, Québec, G1K 7P4, Canada \\ ${ }^{\mathrm{b}}$ Ministère des Ressources naturelles et de la faune du Québec, Direction de la recherche forestière, \\ 2700 rue Einstein, Sainte-Foy, Québec, G1P 3W8, Canada
}

(Received 20 May 2004; accepted 31 August 2004)

\begin{abstract}
To predict the reduction in growth of balsam fir (Abies balsamea (L.) Mill.) subjected to spruce budworm (Choristoneura fumiferana (Clem.)) epidemics, tree-ring chronologies of dominant trees were related to historical records of defoliation collected in the province of Quebec, Canada. These trees were sampled on 136 sites and were harvested for stem analyses that allowed us to calculate indexed radial growth and tree volume increment for a period (1965-1995) that covers the last insect outbreak. Defoliation variables explained 36\% and $23 \%$ of the annual changes in ring width index and annual volume increment index, respectively. Defoliation that dated back by as much as six years affected current-year growth whereas current-year defoliation had limited impact. Several severe annual defoliation events reduced volume growth of dominant balsam fir by $50 \%$ over a 10 -year period. These results can help predict future growth reduction among dominant balsam fir trees subjected to different scenarios of spruce budworm defoliation over broad areas.
\end{abstract}

balsam fir / spruce budworm / defoliation class / growth reduction / stem analysis

Résumé - Prédiction de la réduction de croissance du sapin baumier causée par la tordeuse des bourgeons de l'épinette en utilisant des relevés historiques de défoliation recueillis à grande échelle. Afin de prédire les pertes de croissance de sapins baumiers (Abies balsamea (L.) Mill.) soumis à des épidémies de tordeuse des bourgeons de l'épinette (Choristoneura fumiferana (Clem.)), les séries chronologiques de cernes annuels d'arbres dominants ont été reliées à des relevés historiques de défoliation recueillis dans la province de Québec, Canada. Ces arbres, échantillonnés sur 136 stations, ont été abattus pour faire des analyses de tige qui ont permis de calculer des indices de croissance radiale et d'accroissements en volume pour une période (1965-1995) couvrant la dernière épidémie de cet insecte. Les variables de défoliation expliquent $36 \%$ et $23 \%$ de la variation interannuelle de l'indice de croissance radiale et de l'indice d'accroissement annuel en volume, respectivement. Les défoliations s'étant produites jusqu'à six ans auparavant ont affecté la croissance de l'année courante alors que les défoliations de l'année courante n'ont eu qu'un effet limité. Des défoliations sévères répétées pendant plusieurs années ont diminué de $50 \%$ la croissance en volume des sapins baumiers dominants pendant une période de 10 ans. Ces résultats peuvent contribuer à prédire la future réduction de croissance de sapins baumiers dominants soumis à différents scénarios de défoliation par la tordeuse des bourgeons de l'épinette pour de grands territoires.

sapin baumier / tordeuse des bourgeons de l'épinette / classe de défoliation / réduction de la croissance / analyse de tige

\section{INTRODUCTION}

In the eastern coniferous forests of Canada, spruce budworm (Choristoneura fumiferana (Clem.)) causes large periodic timber losses through extensive tree mortality and growth reduction [2-5, 7, 12]. Its preferred host is balsam fir (Abies balsamea (L.) Mill.) whereas less significant defoliation can also be observed on white spruce (Picea glauca (Moench) Voss.), red spruce ( $P$. rubens Sarg.) and black spruce ( $P$. mariana (Mill.) B.S.P.). A recent historical study based on tree-ring analyses have shown that the frequency of spruce budworm outbreaks has remained quite stable over the last four centuries [9], pre- sumably because of the continuous abundance of balsam fir stands $[8,24,25]$. Since fir-dominated stands are still abundant and are expected to remain so into the future, sustained management of these forests must consider the impact of future insect defoliation by integrating estimation of wood losses in volume prediction models.

Balsam fir volume growth can be reduced by as much as $50 \%$ at the end of a 10-year period from spruce budworm defoliation $[2,19]$. However, when consecutive events of defoliation occur over many years, wood volume lost to mortality becomes increasingly significant and the relative contribution of growth reduction to total volume losses decreases accordingly [2].

\footnotetext{
* Corresponding author: david.pothier@sbf.ulaval.ca
} 
Table I. Characteristics of the 136 sampled balsam fir stands at the time of the last inventory (1998-2002).

\begin{tabular}{lcccc}
\hline & Mean & Standard dev. & Minimum & Maximum \\
\hline dbh $(\mathrm{cm})$ & 16.2 & 2.6 & 8.8 & 25.8 \\
Dominant height $(\mathrm{m})$ & 15.7 & 2.7 & 34 & 22.2 \\
$\mathrm{Age}$ & 75 & 21 & 6.0 & 159 \\
$\mathrm{SI}(\mathrm{m})$ & 13.8 & 3.6 & 100 & 24.8 \\
$\mathrm{~N}_{\mathrm{m}}$ & 1310 & 533 & 0.6 & 2600 \\
$\mathrm{G}_{\mathrm{m}}\left(\mathrm{m}^{2} / \mathrm{ha}\right)$ & 28.3 & 9.1 & 61.2 \\
\hline
\end{tabular}

$\mathrm{dbh}$ is the mean diameter at breast height (1.3 $\mathrm{m}$ above ground level) of the plot; dominant height is the average height of the three largest trees per plot; age is the average number of rings counted on discs sampled at $15 \mathrm{~cm}$ above ground level for three trees per plot; SI is site index at a reference age of 50 years; $\mathrm{N}_{\mathrm{m}}$ is the number of merchantable trees per hectare; and $\mathrm{G}_{\mathrm{m}}$ is the merchantable basal area per hectare.

Mortality attributable to spruce budworm generally begins after $4-5$ years of moderate to severe defoliation $[5,18,21]$ but seems to be highly variable from region to region and even from stand to stand within a region $[12,18]$. This spatial variation of mortality can be explained by differences in stand maturity $[12,19]$, regional defoliation pattern $[14]$ and/or species composition at the stand level and at the landscape level $[6,26,30]$. Even though growth reduction of live trees at the end of a severe outbreak could be less extensive in comparison to mortality, it nevertheless remains a significant component of volume losses and thus needs to be quantified. Moreover, defoliation-induced mortality may be preceded by growth reductions from which patterns of change, as predicted by yearly defoliation, could potentially help estimate volumes lost to mortality.

Regression models relating radial or volume growth to defoliation or larval density have been fitted for different insect and host species (e.g. [1, 3, 11, 23, 29]). However, these models have been calibrated with data often collected on restricted areas and/or over relatively short periods of time that limit their use in sustained yield calculations applied to large territories. On the scale of the province of Quebec, Gray et al. [14] analyzed historical records of defoliation by spruce budworm and observed numerous spatial and temporal patterns that differed in their overall impact. These historical records of defoliation were developed from terrestrial and aerial surveys carried out annually since 1968 and thus represent a long-term and largescale source of data. Despite the relative imprecision of these surveys at the plot or tree level, they present a valuable potential for incorporating volume losses into sustained yield calculations since they cover a complete cycle of spruce budworm outbreak over a very large territory. Growth loss predictions stemming from these historical records could thus be used to forecast the effect of different potential scenarios of spruce budworm defoliation. Moreover, such predictions can help update information from past inventories that are required as input by a sustained yield model when defoliation occurred between the time of inventory and the starting year of calculations.

Therefore, the general objective of this study is to test the predictive capacity of the historical records of defoliation to explain the growth pattern of individual balsam fir trees as derived from stem analyses. The related specific objectives are to: (1) isolate the respective impact of two classes of defoliation level on diameter and volume growths; (2) determine the specific effects of past- and current-year defoliation on growth of balsam fir; and (3) quantify volume losses of individual trees for incorporation into various potential scenarios involving spruce budworm defoliation.

\section{MATERIALS AND METHODS}

\subsection{Sampled stands}

The stands sampled for this study were selected from a network of permanent sample plots (PSPs) established by the Ministère des Ressources naturelles et de la faune du Québec beginning in 1970. PSP selection was based on several criteria. First, a stand composition criterion was applied to limit the scope of this study to balsam fir stands, which were defined as stands composed of at least $50 \%$ of merchantable basal area in balsam fir. Second, since the most recent spruce budworm outbreak began during the 1970s, we selected PSPs that were established before 1980 wherever possible. The stand composition criterion was applied to the first inventory that was generally performed at the beginning of or during the outbreak. This criterion was not applied to later inventories of PSPs, even if mortality caused by insect defoliation decreased the fir proportion of some stands. Third, we avoided PSPs that were located at more than $800 \mathrm{~m}$ from an accessible road so as to facilitate transportation of stem analysis materials. Fourth, we tried to distribute the PSPs uniformly across the natural range of balsam fir stands in the province of Quebec. The application of these criteria resulted in the selection of 136 PSPs whose locations are illustrated in Figure 1, whereas their main characteristics are summarized in Table I.

\subsection{Sampling procedure}

The selected PSPs were located and inventoried again during the snow-free periods between 1998 and 2002. The inventory consisted in measuring the diameter at breast height $( \pm 1 \mathrm{~mm})$ of each tree larger than $9.0 \mathrm{~cm}$ within the $400 \mathrm{~m}^{2}$ circular plot and in measuring the height of three dominant balsam fir trees $( \pm 0.1 \mathrm{~m})$. According to the measured diameter of the four largest balsam fir trees per plot (i.e. 100 largest fir trees/ha), two to three dominant fir trees were then selected in the vicinity of the plot at a distance of at least $25 \mathrm{~m}$. These trees were harvested and sample discs (3-cm thick) were cut at $0.15,0.60,1.00$, 1.30 and $2.00 \mathrm{~m}$, and then at each meter along the main stem. These discs were transported to the laboratory, where they were sanded (grit \# 400), measured and digitized for stem analyses.

\subsection{Tree-ring analyses}

For each fir selected for stem analysis $(n=363)$, the disc sampled at breast height $(1.3 \mathrm{~m})$ was used to analyze tree-ring series. At this height, these discs were composed of at least 50 annual growth rings. 


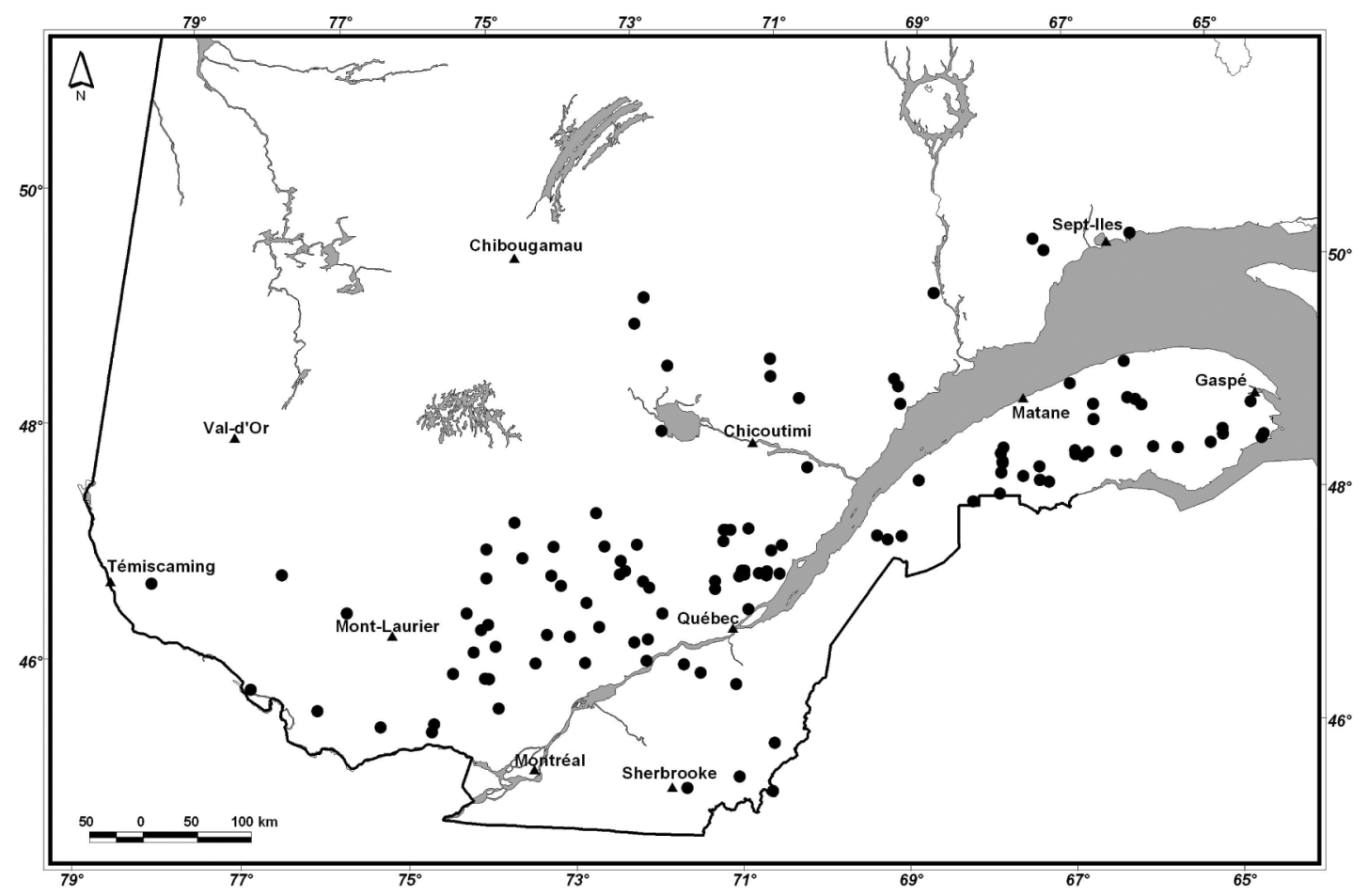

Figure 1. Location of the 136 permanent sample plots near which dominant balsam fir trees were cut for stem analyses.

Four radii of each sampled disc were digitized: the first radius was determined at $22.5^{\circ}$ (clockwise) of the largest disc diameter and the three other radii were located at $90^{\circ}, 180^{\circ}$ and $270^{\circ}$ of the first. Dating of each ring series was done using all the discs sampled for each tree. First, very large or very narrow rings were pointed on discs sampled in the tree bole since missing rings rarely occur in this part of the tree. Second, these diagnostic rings were identified on discs sampled lower down the tree and their dating allowed us to detect missing rings. The dating of all the discs of the same tree was then checked with COFECHA [15]. The dating of diagnostic rings was also checked between trees located on the same site, but not between sites because different diagnostic rings can likely be pointed out in such broad sampling area (Fig. 1). Corresponding ring widths of the four radii were then averaged to produce tree-ring series. Because trees sampled at each site had similar age, height and crown class, their ring width series were averaged to produce a single ring width chronology for each site. The presence or absence of suppression at the juvenile stage and successive spruce budworm outbreaks of varying intensities often obscure the typical ring width decrease that is observable over time. It thus proved difficult to select a fitting model so as to eliminate long term growth trends. Because shorter-term growth trends were easier to determine, we only analyzed the 1965-1995 period that entirely includes the last insect outbreak. This ring width chronology was then standardized using a simple linear regression model in order to retain low-frequency variations associated with insect defoliation while removing longer-term growth trend due to ageing. Following Fritts [13], each ring-width value was then divided by the value of the corresponding fitted line for that year, producing series of ring width indices.

\subsection{Height and volume reconstruction}

The 11 to 26 discs taken on each sample tree allowed us to reconstruct their height and volume development according to standard procedures for stem analyses [10]. The height of the trees at each year was determined by assuming that the height growth between two sections is linear. The site index (height at 50 years) was estimated using the height reconstruction of each tree after a correction was applied to eliminate the effect of suppressed growth at the juvenile stage. This correction consisted of determining the number of years of suppressed growth and then applying the linear height growth of the subsequent years to the suppression period. Suppressed growth was defined as the very small height growth (usually less than $5 \mathrm{~cm} /$ year) occurring when trees were shorter than $3 \mathrm{~m}$ and that was followed by a relatively long period of normal height growth (generally more than $20 \mathrm{~cm} /$ year). The total tree volume of each tree was estimated using Smalian's formula [16].

\subsection{Defoliation record}

Balsam fir ring width and volume increment chronologies were related to insect defoliation records estimated from aerial surveys made annually by the same team of observers. As described by Gray et al. [14], these defoliation surveys were made by the Ministère des Ressources naturelles et de la faune du Québec for the entire balsam fir range of the province of Quebec. These surveys consisted of parallel (south-north) flight lines, 5-10 km apart, at an altitude of 180-250 m. Cells of 5 minutes (latitude) by 5 minutes (longitude) were then formed and identified by the coordinates of their centers. An average level of tree defoliation was assigned to each of these cells, which averaged $58 \mathrm{~km}^{2}$ in size. The tree defoliation codes were: 0 , no observable defoliation; 1 , light defoliation $(<35 \%)$; and 2 , moderate to severe defoliation $(35 \%)$. In the figures, however, light and moderate to severe defoliations were set at $25 \%$ and $50 \%$, respectively. Even though these defoliation classes seem rather broad, the defoliation level separating these two classes correspond to a critical value below which survival rates is quite stable [12]. The surveys were conducted from late June in the southwest of the province to early August in the northeast according to regional climate and tree phenology. 
Table II. Significant $(p<0.05)$ parameter values and related statistics of the multiple linear regression models relating ring width index and annual volume increment index of balsam fir to defoliation classes.

\begin{tabular}{lcc}
\hline & RWI & AVII \\
\hline Intercept & 1.0085 & 1.0198 \\
$\mathrm{NbS}$ & $0.0167(0.0418)$ & $0.0160(0.0238)$ \\
$\mathrm{S}_{\mathrm{n}}$ & - & $-0.0267(0.0005)$ \\
$\mathrm{L}_{\mathrm{n}-1}$ & $-0.0234(0.0006)$ & - \\
$\mathrm{S}_{\mathrm{n}-1}$ & $-0.1490(0.0868)$ & $-0.1593(0.0531)$ \\
$\mathrm{L}_{\mathrm{n}-2}$ & $-0.0244(0.0001)$ & - \\
$\mathrm{S}_{\mathrm{n}-2}$ & $-0.1739(0.1488)$ & $-0.1715(0.0999)$ \\
$\mathrm{L}_{\mathrm{n}-3}$ & $-0.0324(0.0005)$ & - \\
$\mathrm{S}_{\mathrm{n}-3}$ & $-0.1330(0.0662)$ & $-0.1198(0.0361)$ \\
$\mathrm{L}_{\mathrm{n}-4}$ & $-0.0306(0.0005)$ & - \\
$\mathrm{S}_{\mathrm{n}-4}$ & $-0.0760(0.0115)$ & $-0.0667(0.0072)$ \\
$\mathrm{S}_{\mathrm{n}-5}$ & - & $-0.0198(0.0022)$ \\
$\mathrm{S}_{\mathrm{n}-6}$ & - & $-0.0222(0.0031)$ \\
$\mathrm{RMSE}$ & 0.2357 & 0.3406 \\
$R^{2}$ & 0.3568 & 0.2259 \\
\hline
\end{tabular}

These models have the form: $\mathrm{Y}=\mathrm{b}_{0}+\mathrm{b}_{1} \mathrm{NbS}+\mathrm{b}_{2} \mathrm{~S}_{\mathrm{n}}+\ldots+\mathrm{b}_{\mathrm{i}} \mathrm{S}_{\mathrm{n}-6}$ where $\mathrm{Y}$ is RWI (ring width index) or AVII (annual volume increment index), $\mathrm{b}_{0}$ is the intercept, $\mathrm{NbS}$ is the number of years of moderate to severe defoliation, and $b_{1}$ to $b_{i}$ are the parameters to estimate. The names of the other variables refer to defoliation codes that are composed of the defoliation level $(\mathrm{L}=$ light and $\mathrm{S}=$ moderate to severe $)$ and the year of defoliation where $\mathrm{n}$ corresponds to the current year of defoliation. RMSE is the root mean square of error and $R^{2}$ is the coefficient of determination. Numbers in parentheses are partial $R^{2}$ that correspond to the additional amount of variation explained by the introduction of each new variable in the model.

The geographical information of each cell was used to assign a historical defoliation record to each site where balsam fir was sampled for stem analysis according to the known latitude and longitude of adjacent permanent sample plots. A database was then formed to relate tree annual growth indices to defoliation of the current year as well as of the previous 10 years of defoliation. Moreover, for each year of defoliation, two variables were created to distinguish the impact of light defoliation from that of moderate to severe defoliation.

\subsection{Radial and volume increment losses}

Radial and volume increment losses were assessed on the basis of standardized ring width and periodic annual increment in volume, respectively, in order to eliminate the effect of tree ageing and initial tree size on growth loss estimations. Since we tried to evaluate growth losses due to insect defoliation only, we used a regression model relating ring width or volume increment indices to the defoliation characteristics of each plot. Growth losses were estimated by subtracting the predicted growth during the outbreak from the potential growth during the same years. Predicted growth was computed as the estimates of the entire model (Tab. II) for a given number of years, and potential growth was calculated as the summation of the positive terms of the model. These growth losses were expressed as percentages of the reference level. To compute losses of tree volume in $\mathrm{dm}^{3}$, we applied the above \% growth losses to the annual increment in volume inferred from stem analyses.

\subsection{Statistical analyses}

The modelling of ring width and volume increment indices as a function of defoliation of the current and the past 10 years was performed using the MIXED procedure of the SAS system that calculates the parameters of a multiple linear regression model. The time series that characterized each tree-ring chronology were taken into account by using an autoregressive covariance structure. This technique was used to remove the correlation between successive ring widths of the same individual and allowed us to calculate unbiased statistics associated with the regression model. Since our objectives aimed at assessing the impact of the two defoliation classes occurring at different periods in the past, we first submitted all the defoliation and site variables to the model. Then, to determine the variables that played a significant role in explaining the variation of ring width index and annual volume increment index, we successively eliminated those that were not significant $(p>0.05)$, beginning with the largest $p$-value.

\section{RESULTS AND DISCUSSION}

\subsection{Model fitting}

The statistical analyses applied to the tree-ring chronologies resulted in fitted multiple linear regressions that related ring width index to defoliation variables but not to site variables such as site index (Tab. II). Defoliation variables explained $36 \%$ of the interannual changes in ring width index of dominant balsam fir trees that survived the outbreak (Tab. II). Although this $R^{2}$ value can appear modest, we believe rather that it constitutes an important contribution to the explanation of the variation of ring width index considering the coarse defoliation estimates (three categories) and the scaling difference between defoliation assessments $\left(\sim 58 \mathrm{~km}^{2}\right)$ and projected tree area $\left(\sim 10 \mathrm{~m}^{2}\right)$. Moreover, other sources of interannual variation of ring width index are not included in the model. Past- and current-year temperature and precipitation are examples of such variables that can explain a large part of the interannual variation of ring width index [13]. Considering that the model was fitted using 136 ring width series covering a large range of defoliation patterns and that the residuals are well distributed (not shown), it appears that the relationship is quite robust and reliable. 


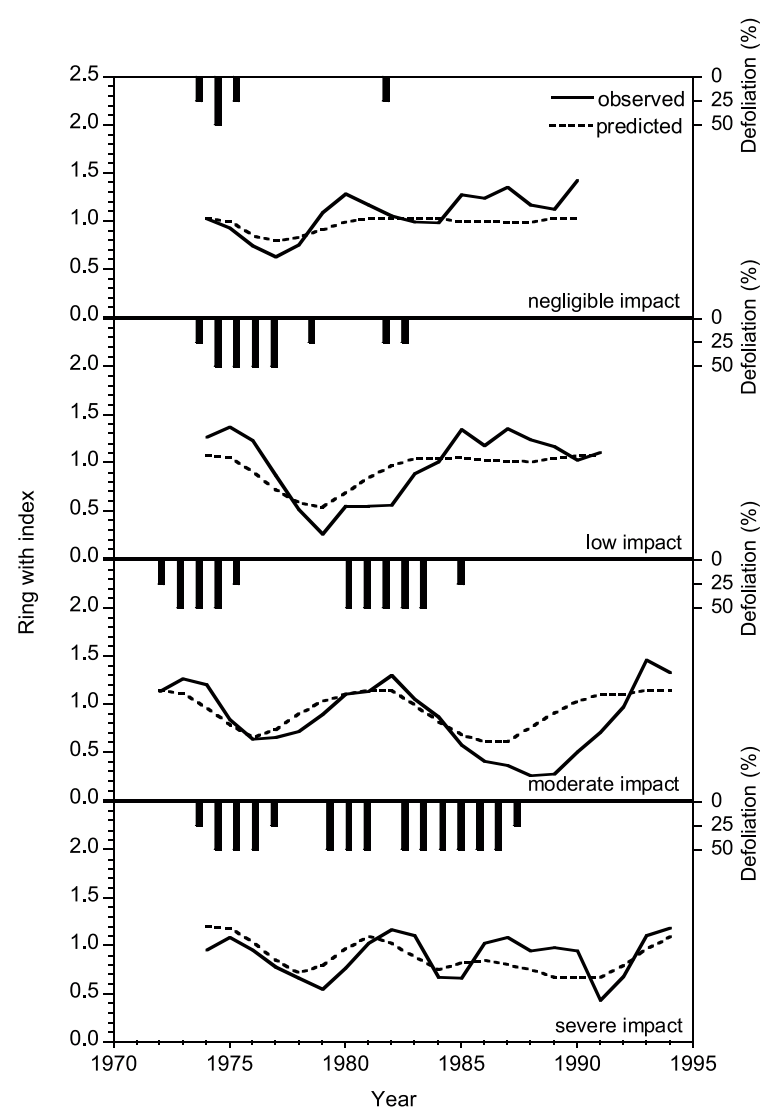

Figure 2. Observed (solid line) and predicted (dotted line) ring width index for dominant balsam fir subjected to the four levels of defoliation impact proposed by Gray et al. [14]. Annual defoliation is represented by vertical bars. These dominant balsam fir trees were located near four randomly selected plots among the 136 sampled plots: plot 048 (negligible impact), plot 055 (low impact), plot 090 (moderate impact), and plot 031 (severe impact). Predicted values were calculated according to the model and the parameters presented in Table II.

In Figure 2, the model was adjusted to four different defoliation patterns that correspond to the four classes of defoliation impact proposed by Gray et al. [14]. Over the duration of the outbreak, predicted values followed the observed variations in ring width index, especially when defoliation caused important drops of radial increment (Fig. 2). Incidentally, the model includes a variable $(\mathrm{NbS})$ that increases the magnitude of these drops with increasing number of years during which moderate to severe defoliation occurs (Tab. II). Comparisons of parameter values within each year of past defoliation indicates that severe defoliation has 2 to 7 times more impact on ring width index than light defoliation (Tab. II). Baskerville and Kleinschmidt [3] also observed this minor effect of light defoliation events on growth losses even when they are repeated over many consecutive years. It would appear that the carbon fixed by the foliage that remains after light defoliation is sufficient to maintain normal diameter growth at breast height. In the tree bole and in the root system, however, light defoliation could produce a negative impact on ring width [17].

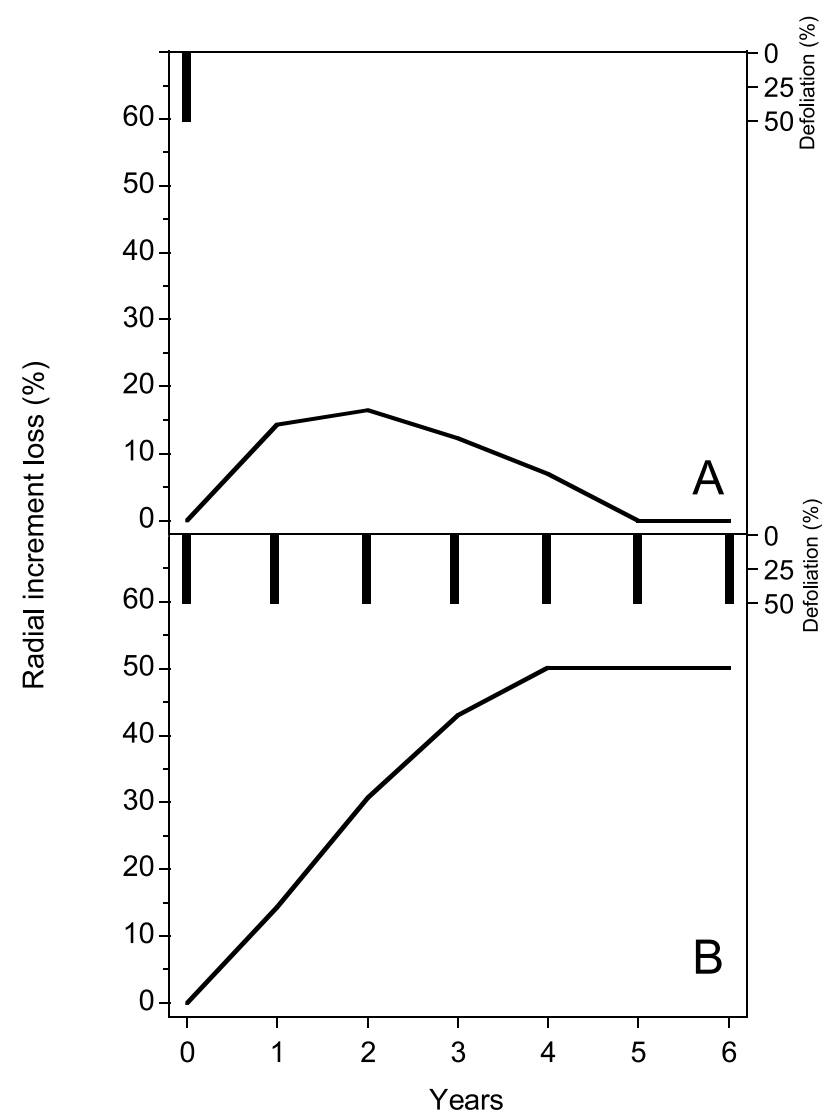

Figure 3. Predicted radial increment loss (solid line) of a dominant balsam fir that survived the outbreak and that was subjected to one (A) and seven (B) consecutive years of moderate to severe defoliation (bars). Predicted radial increment losses were calculated as the ratio between the predictive value of the model presented in Table II when all the parameters are used and that of the same model when only the positive parameters are used.

In our predictive model, the past four years of defoliation negatively affected ring width index measured at breast height whereas current-year defoliation had no significant effect (Tab. II). Many authors have previously observed a lag of one or more years between defoliation and tree growth response for a variety of insects and host species [1, 3, 5, 7, 23]. This lag response can be explained by the relatively low larval population generally occurring at the beginning of an outbreak, which results in the consumption of only current-year needles [19] and, consequently, in a limited impact on current-year diameter growth.

\subsection{Growth losses}

Using the parameters of the ring width index model for the 1970-1990 spruce budworm outbreak (Tab. II), we calculated the losses in radial increment at breast height resulting from one year of defoliation (Fig. 3A). The largest impact was produced two years after defoliation, although significant growth losses were also observed in the first and the third year after defoliation (Fig. 3A). By the fifth year following defoliation, no observable 
radial growth reduction was predicted, and the dominant fir trees have likely completed their foliage recovery, which seems to be favoured by their ability to produce epicormic shoots [27, 28].

Regression parameters of the 1970-1990 outbreak were also used to simulate the radial increment losses produced by many years of consecutive defoliation events (Fig. 3B). Predicted growth losses increased almost linearly during the first four years after the first defoliation and then reached a plateau at around $50 \%$ of radial growth reduction (Fig. 3B). This plateau possibly corresponds to the maximum growth loss that a dominant balsam fir can suffer without deteriorating in mortality. For long periods of moderate to severe defoliation, diameter growth of less vigorous trees likely continues to decrease beyond the plateau value of $50 \%$. This plateau could thus indicate a threshold over which tree mortality induced by spruce budworm defoliation begins. Accordingly, many authors have reported that trees usually start to die after four to five years of severe defoliation $[1,5,7,18,21]$. Therefore, the pattern of radial growth reduction, as predicted from defoliation scenarios, could be useful to empirically forecast volume loss from mortality.

The procedure used to standardize ring width chronological series was also applied to the annual volume increment series derived from stem analyses. The result of this standardization, the annual volume increment index, was then correlated with defoliation variables (Tab. II). Defoliation variables that significantly explained annual volume increment index were all related to moderate to severe defoliation. Hence, light defoliation seemed to have negligible impact on volume growth of dominant trees. Moreover, current-year volume increment was affected by moderate to severe defoliation that occurred the same year and that dated back as long as six years (Tab. II). These results differ from those obtained with ring width index measured at breast height which was not affected by currentyear defoliation as well as by defoliation occurring prior to four years ago. These differences could be explained by varying diameter growth responses along the stem [17], all of which have been integrated into the calculation of the annual volume increment index.

From the relationship between annual volume increment index and defoliation variables (Tab. II), volume growth changes were calculated for four defoliation scenarios (Fig. 4) that correspond to the four classes of defoliation impact proposed by Gray et al. [14]. For a period of 30 years, a time roughly equivalent to the return interval of the recent spruce budworm outbreak [9], these volume losses were estimated at $2,8,15$ and $24 \%$ for the negligible, light, moderate, and severe classes of defoliation impact, respectively. Similar results have been derived from a process-based model developed by Baskerville and Kleinschmidt [3] for balsam fir stands subjected to defoliation by spruce budworm in north-central Maine and New Brunswick. Other authors have reported growth losses of approximately $50 \%$ when the impact of six years or more of severe defoliation was averaged over a 10-year period $[2,19,20]$. These growth losses correspond to the moderate to severe defoliation scenarios calculated with the equation of Table II for a period of 10 years. Therefore, the estimation of growth losses on the basis of the relationship between annual volume increment index and defoliation variables seems reliable and confirms that such factors can contribute substantially to the total stand volume losses (mortality + growth loss).

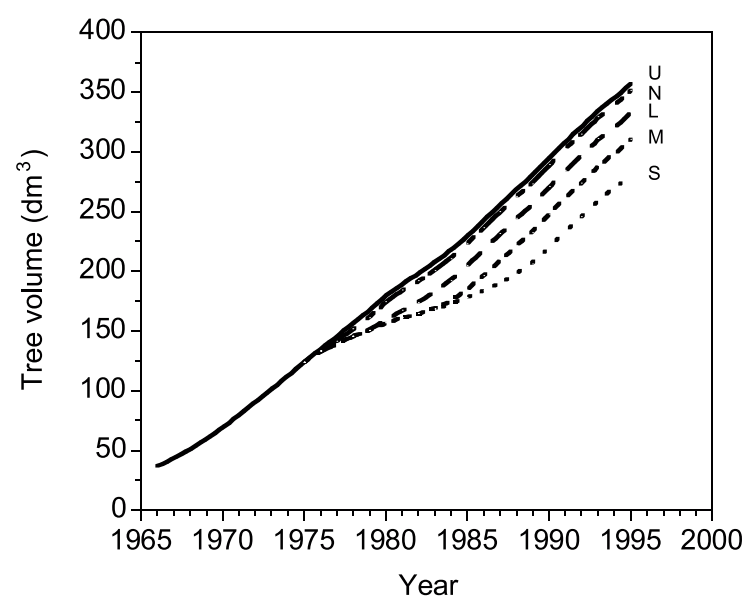

Figure 4. Predicted volume changes over time of a hypothetical dominant balsam fir that was never defoliated (U) and that was subjected to the four classes of defoliation impact following different patterns of annual defoliation that were proposed by Gray et al. [14]: negligible $(\mathrm{N})$, low (L), moderate (M), and severe (S). Volume increment losses were calculated as the ratio between the predictive value of the model presented in Table II when all the parameters are used and that of the same model when only the positive parameters are used.

\section{CONCLUSION}

Even though they are rough estimates, the defoliation classes stemming from large-scale aerial surveys explained an important part of the growth variation of dominant balsam fir trees affected by the last spruce budworm outbreak. Thus, even at this point, this defoliation dataset offers two main advantages. First, it can be used to work up realistic scenarios of future spruce budworm defoliation (e.g. [14]) given that the abundance, distribution and vulnerability of host species will be similar to those during the last outbreak. Second, based on the relationships developed in the present study, it is possible to estimate the growth losses of dominant balsam fir trees that survived the outbreak. Further, these growth losses could help calibrate a model that would predict future yield of balsam fir stands subjected to different scenarios of spruce budworm defoliation (e.g. [22]). Such a model, together with realistic defoliation scenarios, are needed to improve sustained yield calculations that determine the annual allowable cut over periods of time that can cover two or three epidemic cycles. In addition to growth losses, a balsam fir growth and yield model must take into account volume lost to mortality. The next step in developing such a model will thus consist of estimating volume losses due to mortality for different spruce budworm defoliation patterns using permanent sample plots that cover the natural range of balsam fir in Quebec.

Acknowledgements: We thank Luc Duchesne, Carl Lemieux, François Lacombe, Gilles Audy, Simon Pouliot, and many summer students for their help in the field and laboratory. We are indebted to the Direction de la conservation des forêts and the Direction des inventaires forestiers of the Ministère des Ressources naturelles et de la faune du Québec for providing us the defoliation and the PSP datasets used in this study. We also thank Jean Noël for drawing the map in Figure 1 and Bruno Boulet, Donald Kellough and two anonymous reviewers for helpful comments on the manuscript. 


\section{REFERENCES}

[1] Alfaro R.I., Van Sickle G.A., Thomson A.J., Wegwitz E., Tree mortality and radial growth losses caused by the western spruce budworm in a Douglas-fir stand in British Columbia, Can. J. For. Res. 12 (1982) 780-787.

[2] Archambault L., Beaulieu J., Réduction de croissance en volume occasionnée au sapin baumier, suite à la défoliation par la tordeuse des bourgeons de l'épinette, For. Chron. 61 (1985) 10-13.

[3] Baskerville G., Kleinschmidt S., A dynamic model of growth in defoliated fir stands, Can. J. For. Res. 11 (1981) 206-214.

[4] Beaulieu J., Hardy Y.J., Mortalité du sapin baumier défolié par la tordeuse des bourgeons de l'épinette dans la région de la Gatineau au Québec, For. Chron. 58 (1982) 213-221.

[5] Belyea, R.M., Death and deterioration of balsam fir weakened by spruce budworm defoliation in Ontario. Part II. An assessment of the role of associated insect species in the death of severely weakened trees, J. For. 50 (1952) 729-738.

[6] Bergeron Y., Leduc A., Morin H., Joyal C., Balsam fir mortality following the last spruce budworm outbreak in northwestern Quebec, Can. J. For. Res. 25 (1995) 1375-1384.

[7] Blais J.R., Effects of defoliation by spruce budworm (Choristoneura fumiferana $\mathrm{Clem}$.) on radial growth at breast height of balsam fir (Abies balsamea (L.) Mill.) and white spruce (Picea glauca (Moench) Voss.), For. Chron. 34 (1958) 39-47.

[8] Blais J.R., Trends in the frequency, extent, and severity of spruce budworm outbreaks in eastern Canada, Can. J. For. Res. 13 (1983) 539-547.

[9] Boulanger Y., Arseneault D., Spruce budworm outbreaks in eastern Quebec over the last 450 years, Can. J. For. Res. 34 (2004) 10351043.

[10] Carmean W.H., Site index curves for upland oaks in the central states, For. Sci. 18 (1972) 102-120.

[11] Dobesberger E.J., Stochastic simulation of growth loss in thinned balsam fir stands defoliated by the spruce budworm in Newfoundland, Can. J. For. Res. 28 (1998) 703-710.

[12] Erdle T.A., MacLean D.A., Stand growth model calibration for use in forest pest impact assessment, For. Chron. 75 (1999) 141-152.

[13] Fritts H.C., Tree rings and climate, Academic Press, New York, 1976.

[14] Gray D.R., Régnière J., Boulet B., Analysis and use of historical patterns of spruce budworm defoliation to forecast outbreak patterns in Quebec, For. Ecol. Manage. 127 (2000) 217-231.

[15] Holmes R.L., Computer-assisted quality control in tree-ring dating and measurement, Tree-ring Bull. 44 (1983) 69-75.
[16] Husch B., Miller C.I., Beers T.W., Forest mensuration, 3rd ed., Krieger Publishing Company, Melbourne, USA, 1993.

[17] Krause C., Morin H., Changes in radial increment in stems and roots of balsam fir [Abies balsamea (L.) Mill.] after defoliation by spruce budworm, For. Chron. 71 (1995) 747-754.

[18] MacLean D.A., Vulnerability of fir-spruce stands during uncontrolled spruce budworm outbreaks: a review and discussion, For. Chron. 56 (1980) 213-221.

[19] MacLean D.A., Effects of spruce budworm outbreaks on the productivity and stability of balsam fir forests, For. Chron. 60 (1984) 273-279.

[20] MacLean D.A., Hunt, T.L., Eveleigh E.S., Morgan M.G., The relation of balsam fir volume increment to cumulative spruce budworm defoliation, For. Chron. 72 (1996) 533-540.

[21] MacLean D.A., Piene H., Spatial and temporal patterns of balsam fir mortality in spaced and unspaced stands caused by spruce budworm defoliation, Can. J. For. Res. 25 (1995) 902-911.

[22] MacLean D.A., Erdle T.A., MacKinnon W.E., Porter K.B., Beaton K.P., Cormier G., Morehouse S., Budd M., The spruce budworm decision support system: forest protection planning to sustain longterm wood supply, Can. J. For. Res. 31 (2001) 1742-1757.

[23] Mason R.R., Wickman B.E., Paul H.G., Radial growth response of Douglas-fir and grand fir to larval densities of the Douglas-fir tussock moth and the western spruce budworm, For. Sci. 43 (1997) 197-205.

[24] Morin H., Analyse dendroécologique d'une sapinière issue d'un chablis dans la zone boréale, Québec, Can. J. For. Res. 20 (1990) $1753-1758$

[25] Morin H., Laprise D., Bergeron Y., Chronology of spruce budworm outbreaks near Lake Duparquet, Abitibi region, Quebec, Can. J. For. Res. 23 (1993) 1497-1506.

[26] Needham T., Kershaw J.A. Jr., MacLean D.A., Su Q., Effects of mixed stand management to reduce impacts of spruce budworm defoliation on balsam fir stand-level growth and yield, North. J. Appl. For. 16 (1999) 19-24.

[27] Ostaff D.P., MacLean D.A., Patterns of balsam fir foliar production and growth in relation to defoliation by spruce budworm, Can. J. For. Res. 25 (1995) 1128-1136.

[28] Piene H., Spruce budworm defoliation and growth loss in young balsam fir: defoliation in spaced and unspaced stands and individual tree survival, Can. J. For. Res. 19 (1989) 1211-1217.

[29] Steinman J.R., MacLean D.A., Predicting effects of defoliation on spruce-fir stand development: a management-oriented growth and yield model, For. Ecol. Manage. 69 (1994) 283-298.

[30] Su Q., MacLean D., Needham T.D., The influence of hardwood content on balsam fir defoliation by spruce budworm, Can. J. For. Res. 26 (1996) 1620-1628. 